\title{
Vertical distribution and population structure of the necrophagous amphipod Eurythenes gryllus in the West European Basin*
}

\author{
B. Christiansen ${ }^{1}$, O. Pfannkuche ${ }^{2}$, H. Thiel ${ }^{1}$ \\ ${ }^{1}$ Institut für Hydrobiologie und Fischereiwissenschaft der Universität Hamburg, Zeiseweg 9, D-2000 Hamburg 50, \\ Federal Republic of Germany \\ ${ }^{2}$ Institut für Meereskunde an der Universität Kiel, Düsternbrooker Weg 20, D-2300 Kiel 1, Federal Republic of Germany
}

\begin{abstract}
During 3 cruises to the West European Basin benthopelagic nekton was captured by use of an acoustically released vertical array of 8 to 10 baited traps. The traps were exposed from 5 to $1000 \mathrm{~m}$ above the bottom. Nearly all of the 1692 amphipods trapped in total during 18 deployments were identified as the lysianassid amphipod Eurythenes gryllus Lichtenstein. Most individuals were recovered from traps deployed $15 \mathrm{~m}$ above the sea floor. Above $30 \mathrm{~m}$, catch rates decreased significantly. However, the vertical distribution differed by age and sex: indeterminate juveniles and adult females were only trapped up to $50 \mathrm{~m}$ above the bottom. Catch rates of juvenile males and females decreased with increasing distance from the bottom, whereas adult males showed a bimodal distribution with maxima at 15 and at $300 \mathrm{~m}$ above the sea floor. Males were prevalent in all but 2 deployments. The characteristic vertical distribution and the population structure at the depths sampled imply an ontogenetic vertical migration of E. gryllus: females release their brood near the bottom. The youngest stages stay within a few meters above the sea floor, whereas older stages, especially adult males, migrate into higher water layers.
\end{abstract}

\section{INTRODUCTION}

Necrophagous amphipods of the family Lysianassidae are important members of the deep-sea benthic and benthopelagic community. The lysianassid amphipod Eurythenes gryllus Lichtenstein is a highly motile, cosmopolitan scavenger which has been reported to occur directly on the sea floor as well as in midwater up to $1800 \mathrm{~m}$ above the bottom (Baldwin \& Smith 1987). The majority of studies on the vertical distribution and population structure of this species have been carried out in the North Pacific (Smith et al. 1979, Ingram \& Hessler 1983, 1987, Smith \& Baldwin 1984, Baldwin \& Smith 1987, Bucklin et al. 1987). Reports from the Atlantic have so far been restricted to the near-bottom water layer up to $200 \mathrm{~m}$ above the sea floor (Thurston 1979, Wickins 1983, Charmasson \& Calmet 1987).

This paper present results from a sampling programme which was part of the German multidisciplinary research project BIOTRANS. This project studies

- BIOTRANS publication no. 17 the BIOlogical vertical TRANSport of organic matter and energetics in the benthic boundary layer of the deep-sea up to $500 \mathrm{~m}$ above the sea bottom (Thiel 1986). Scavenging amphipods were caught in sets of baited traps exposed at various distances from the sea floor to a maximum of $1000 \mathrm{~m}$. The population structure of Eurythenes gryllus at different depths was analysed to investigate the role of this large amphipod in the vertical transport of organic matter. Although we have no final answer to this question, the alteration in population structure of $E$. gryllus with increasing distance from the sea bed allows some conclusions on the biology and on ontogenetic migrations of this species.

\section{STUDY SITE}

The site of investigation was the BIOTRANSresearch area (Fig. 1) in the West European Basin, NE Atlantic, within the coordinates $47^{\circ}$ to $47^{\circ} 30^{\prime} \mathrm{N}, 19^{\circ}$ to $20^{\circ} \mathrm{W}$. Sea beam mapping of the area and its surroundings (Heinrich 1986) revealed a variable bottom topography. It is structured by a system of ridges and furrows 


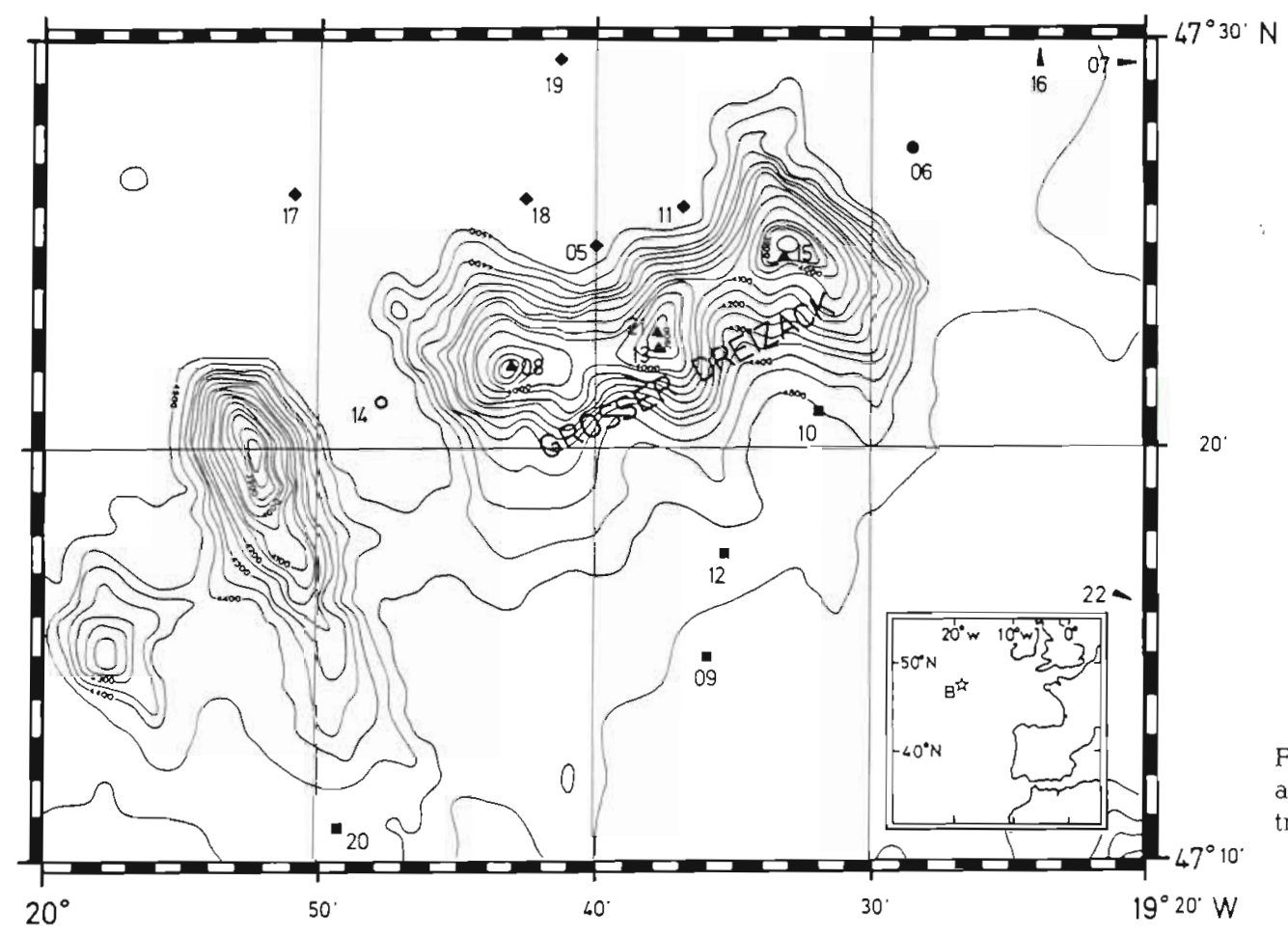

Fig. 1. BIOTRANS research area with the positions of trap deployments indicated by their numbers

stretching more or less parallel to the Mid-Atlantic Ridge (NNE to SSW). At the BIOTRANS site a seamount characterized by 3 peaks named 'Grosser Dreizack' stands apart from the NNE to SSW lying ridges. The Grosser Dreizack is surrounded on 3 sides by broad valleys of about $15 \mathrm{n}$ miles width. To the west it is separated from a neighbouring ridge by a narrower valley of $4 \mathrm{n}$ miles width. Water depth in the valleys ranges between 4500 and $4560 \mathrm{~m}$. The peaks of the Grosser Dreizack rise to about $700 \mathrm{~m}$ above the valleys or $3800 \mathrm{~m}$ below the sea surface.

The hydrography of the area was described by Mittelstaedt (1986) and Klein (1987). Only slight gradients of temperature and salinity occur below $2000 \mathrm{~m}$ water depth. Salinity of the bottom water is about 34.9 , in situ temperature ranges from 2.54 to $2.63{ }^{\circ} \mathrm{C}$, and oxygen content amounts to 5.5 to $5.7 \mathrm{ml} \mathrm{O}_{2} \mathrm{l}^{-1}$. While the gradients of the physical parameters decrease with decreasing distance from the bottom the particle concentration increases. The thickness of the benthic nepheloid layer (BNL) was determined by Nyffeler \& Godet (1986) to be 800 to $1000 \mathrm{~m}$. The particle concentration reaches a maximum at about 80 to $100 \mathrm{~m}$ above the sea floor. Bottom topography has a strong influence on the extent of the BNL. Current velocities in the layer up to $1500 \mathrm{~m}$ above bottom lie in the range 1 to $4 \mathrm{~cm} \mathrm{~s}^{-1}$. Near-bottom current velocity are frequently 1 to $2 \mathrm{~cm} \mathrm{~s}^{-1}$ greater. 'Deep-sea storms' with maximum current velocities of $27 \mathrm{~cm} \mathrm{~s}^{-1}$ can occur for several days or even weeks (Klein 1987).

\section{MATERIALS AND METHODS}

Scavenging amphipods were caught on 3 crujses in 1985 ('Meteor (I)' 70 and 'Polarstern' 8) and in 1986 ('Meteor (II)' 3) with an acoustically released vertical array of 8 to 10 baited traps. The array construction is shown in Fig. 2 together with the heights of the traps above bottom. Deployments were made in 5 subareas of the BIOTRANS site (Fig. 1): (1) valley north of Grosser Dreizack; (2) valley south of Grosser Dreizack; (3) peaks of Grosser Dreizack; (4) channel east of Grosser Dreizack; (5) channel west of Grosser Dreizack.

The traps were made of PVC tube with a length of $80 \mathrm{~cm}$ and a diameter of $40 \mathrm{~cm}$. An inverted entrance cone, made from gauze netting (mesh width $1 \mathrm{~mm}$ ), was attached at each end with an entrance of $4.5 \mathrm{~cm}$ diameter, allowing the largest known Eurythenes gryllus to enter the trap (Ingram \& Hessler 1983). The design of the mooring used during 'Polarstern' Cruise 8 (1985) is shown in Fig. 2. During 'Meteor (I)' Cruise 70 (1985), no traps were employed at 400 and $500 \mathrm{~m}$ During 'Meteor (II)' Cruise 3 (1986), the set was modified by adding traps at 10 and $5 \mathrm{~m}$. On this cruise, deployments were also made with a single trap in the array moored at $1000 \mathrm{~m}$ above bottom.

Exposure time was 15 to $44 \mathrm{~h}$ for the trap sets and 62 to $74 \mathrm{~h}$ for the single traps. Station data are listed in Table 1

The traps were baited with sliced fish or fish heads (herring, cod) which were placed directly into the traps. 


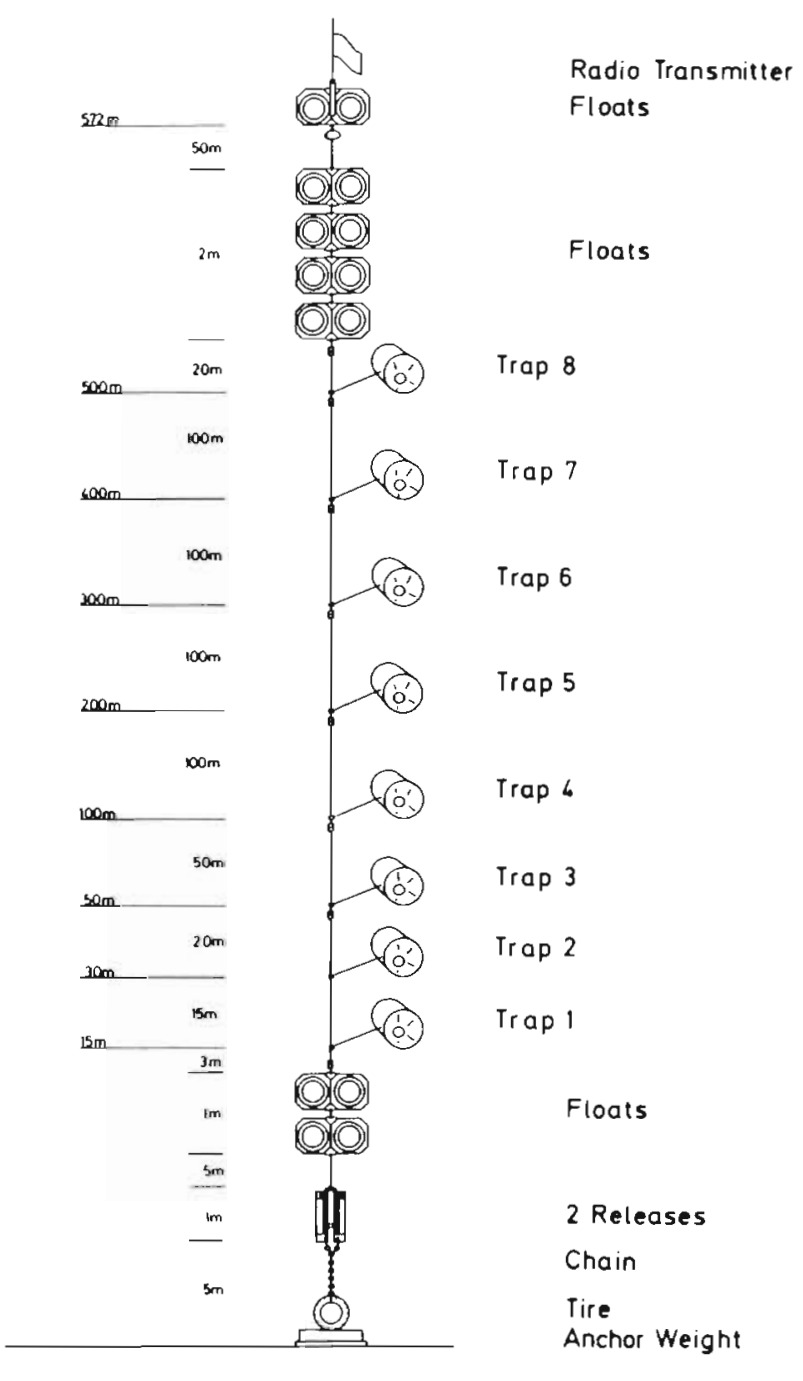

Fig. 2. IHF trap set

For deployment RK 21 the bait was enclosed in perforated containers which prevented the amphipods from feeding on it.

Trapped amphipods were fixed in $4 \%$ buffered formaldehyde and later transferred to $70 \%$ ethanol. Specimens of Eurythenes gryllus were sorted into 5 categories: (1) sexually indeterminate juveniles (no oostegites or genital papillae recognizable); (2) immature males (showing genital papillae); (3) mature males (with calceoli on the antennae); (4) immature females (with oostegites); (5) mature females (oostegites with long interlocking setae)

Determinations of body length were made by straightening the specimen gently on a scale and measuring the distance from the front edge of the head to the tip of the telson to the nearest $0.5 \mathrm{~cm}$. Mean lengths are expressed as geometric means, because the distributions appeared to be positively skewed.

Catch rates were calculated by dividing catch num- bers by exposure time (in days). For tests on vertical differences of abundance a 2-way ANOVA without replication (mixed model) was applied (Sokal \& Rohlf 1969). To achieve homoscedasticity, catch rates were transformed by $y=\ln (x+1)$. Homogeneity of ratios between the 5 categories was tested by a Chi square contingency table (Sachs 1978).

\section{RESULTS}

\section{Taxonomic composition}

A total of 1692 amphipods were trapped in 18 deployments. Of these, 1687 belonged to the species Eurythenes gryllus, 4 were identified as Cyphocaris richardi Chevreux and 1 as $C$. anonyx Boeck. Female E. gryllus had 5 pairs of oostegites, in accordance with specimens caught in the North Pacific (Ingram \& Hessler 1983) and in the North Atlantic (Charmasson \& Calmet 1987). In contrast to these findings, Ingram \& Hessler (1983) reported that female E. gryllus from the Atlantic had only 4 pairs of oostegites.

\section{Mesoscale variation in catches}

The number of amphipods caught in a multi-trap deployment varied from 17 to 309 (Table 2). Normalized for bottom time, catch rates ranged from 17 to 265 ind. deployment ${ }^{-1} \mathrm{~d}^{-1}$. The lowest catch rate was found in Deployment RK 21 with the bait enclosed in perforated containers. This may have affected the effectiveness of the traps, thus the data of this set were excluded from all following calculation.

A regional comparison of mean total catch rates in 1986 revealed that the subareas north and south of the Grosser Dreizack did not differ significantly (Student ttest, log-transformed data). Catches in the other subareas were only represented by single deployments of the array and thus not tested for differences.

\section{Vertical distribution}

The vertical distribution of Eurythenes gryllus (Fig. 3) was similar in all subareas and in both years. In 1986, nearly $50 \%$ of all specimens were caught in the $15 \mathrm{~m}$ traps. For individual deployments, the proportion trapped at this height above bottom varied between 7 and $87 \%$. Below and above $15 \mathrm{~m}$ the number of amphipods decreased significantly (ANOVA, $p<0.05$ and $\mathrm{p}<0.01$, respectively). Only $17 \%$ of all individuals were caught in water layers higher than $30 \mathrm{~m}$ above bottom. However, above $200 \mathrm{~m}$ catch rates were signficantly higher than between 50 and $200 \mathrm{~m}(\mathrm{p}<0.01)$ 
Table 1. List of stations

\begin{tabular}{|c|c|c|c|c|c|c|c|}
\hline \multirow[t]{2}{*}{ Date } & \multirow{2}{*}{$\begin{array}{c}\text { Deployment } \\
\text { no. }\end{array}$} & \multirow{2}{*}{$\begin{array}{l}\text { Stn } \\
\text { no. }\end{array}$} & \multicolumn{2}{|c|}{ Coordinates } & \multirow{2}{*}{$\begin{array}{l}\text { Depth } \\
(\mathrm{m})\end{array}$} & \multirow{2}{*}{$\begin{array}{l}\text { Bottom } \\
\text { time (h) }\end{array}$} & \multirow{2}{*}{$\begin{array}{l}\text { No. of } \\
\text { traps }\end{array}$} \\
\hline & & & North & West & & & \\
\hline \multicolumn{8}{|l|}{1985} \\
\hline 20 May & RK 05 & 117 & $47^{\circ} 25.0^{\prime}$ & $19^{\circ} 40.1^{\prime}$ & 4510 & 44.2 & 6 \\
\hline 17 Sep & RK 06 & 170 & $47^{\circ} 28.0^{\prime}$ & $19^{\circ} 29.2^{\prime}$ & 4524 & 28.0 & 8 \\
\hline 18 Sep & RK 07 & 177 & $47^{\circ} 30.1^{\prime}$ & $19^{\circ} 16.3^{\prime}$ & 4550 & 15.0 & 8 \\
\hline 19 Sep & RK 08 & 183 & $47^{\circ} 22.4^{\prime}$ & $19^{\circ} 43.4^{\prime}$ & 3850 & 17.5 & 8 \\
\hline \multicolumn{8}{|l|}{1986} \\
\hline $26 \mathrm{Jul}$ & RK 09 & 198 & $47^{\circ} 15.2^{\prime}$ & $19^{\circ} 36.9^{\prime}$ & 4554 & 22.7 & 10 \\
\hline $26 \mathrm{Jul}$ & RK 10 & 200 & $47^{\circ} 21.0^{\prime}$ & $19^{\circ} 32.2^{\prime}$ & 4436 & 62.5 & 1 \\
\hline $28 \mathrm{Jul}$ & RK 11 & 212 & $47^{\circ} 26.0^{\prime}$ & $19^{\circ} 37.8^{\prime}$ & 4532 & 23.5 & 10 \\
\hline $30 \mathrm{Jul}$ & RK 12 & 221 & $47^{\circ} 17.7^{\prime}$ & $19^{\circ} 35.1^{\prime}$ & 4526 & 69.7 & 1 \\
\hline $30 \mathrm{Jul}$ & RK 13 & 222 & $47^{\circ} 22.7^{\prime}$ & $19^{\circ} 37.8^{\prime}$ & 3882 & 17.8 & 10 \\
\hline $31 \mathrm{Jul}$ & RK 14 & 229 & $47^{\circ} 21.1^{\prime}$ & $19^{\circ} 47.8^{\prime}$ & 4518 & 23.3 & 9 \\
\hline 3 Aug & RK 15 & 243 & $47^{\circ} 24.7^{\prime}$ & $19^{\circ} 33.3^{\prime}$ & 3849 & 73.8 & 1 \\
\hline $3 \mathrm{Aug}$ & RK 16 & 244 & $47^{\circ} 34.3^{\prime}$ & $19^{\circ} 24.0^{\prime}$ & 4577 & 20.2 & 9 \\
\hline 5 Aug & RK 17 & 258 & $47^{\circ} 26.3^{\prime}$ & $19^{\circ} 50.5^{\prime}$ & 4540 & 19.5 & 9 \\
\hline 7 Aug & RK 18 & 269 & $47^{\circ} 26.0^{\prime}$ & $19^{\circ} 43.1^{\prime}$ & 4531 & 17.0 & 9 \\
\hline $8 \mathrm{Aug}$ & RK 19 & 279 & $47^{\circ} 30.3^{\prime}$ & $19^{\circ} 41.1^{\prime}$ & 4546 & 61.7 & 1 \\
\hline 9 Aug & RK 20 & 282 & $47^{\circ} 10.7^{\prime}$ & $19^{\circ} 49.7^{\prime}$ & 4475 & 20.2 & 9 \\
\hline $11 \mathrm{Aug}$ & RK 21 & 297 & $47^{\circ} 22.8^{\prime}$ & $19^{\circ} 37.9^{\prime}$ & 4053 & 23.5 & 9 \\
\hline 12 Aug & RK 22 & 306 & $47^{\circ} 15.8^{\prime}$ & $19^{\circ} 15.8^{\prime}$ & 4551 & 33.3 & 10 \\
\hline
\end{tabular}

Table 2. Eurythenes gryllus. Total number captured in each trap. Subareas: vs, valley south of Grosser Dreizack; vn, valley north of Grosser Dreizack; p, peaks of Grosser Dreizack; cw, channel west of Grosser Dreizack; ce, channel east of Grosser Dreizack

\begin{tabular}{|c|c|c|c|c|c|c|c|c|c|c|c|c|c|c|c|c|c|c|c|c|}
\hline \multirow{4}{*}{$\begin{array}{l}\text { Trap } \\
\text { height } \\
\text { (m) }\end{array}$} & \multicolumn{20}{|c|}{ Deployment No. } \\
\hline & \multirow{3}{*}{$\begin{array}{l}05 \\
\text { vn }\end{array}$} & \multirow{3}{*}{$\begin{array}{l}06 \\
\text { Sub } \\
\text { ce }\end{array}$} & \multirow{2}{*}{$\begin{array}{l}07 \\
\text { irea }\end{array}$} & \multirow[t]{2}{*}{08} & \multirow{3}{*}{$\begin{array}{l}\text { Total } \\
1985\end{array}$} & \multirow{3}{*}{$\begin{array}{l}09 \\
\text { vs }\end{array}$} & \multirow{3}{*}{$\begin{array}{l}10 \\
\text { vs }\end{array}$} & \multirow{3}{*}{$\begin{array}{l}11 \\
\text { vn }\end{array}$} & \multirow{3}{*}{$\begin{array}{l}12 \\
\text { vs }\end{array}$} & \multirow{3}{*}{$\begin{array}{l}13 \\
p\end{array}$} & & \multirow{2}{*}{\multicolumn{2}{|c|}{$\begin{array}{c}1516 \\
\text { Subarea }\end{array}$}} & \multirow{3}{*}{$\begin{array}{l}17 \\
\text { vn }\end{array}$} & \multirow{3}{*}{$\begin{array}{l}18 \\
\text { vn }\end{array}$} & \multirow{3}{*}{$\begin{array}{l}19 \\
\text { vn }\end{array}$} & & \multirow{3}{*}{$\begin{array}{l}21 \\
p\end{array}$} & & \multirow{3}{*}{$\begin{array}{l}\text { Total } \\
1986\end{array}$} \\
\hline & & & & & & & & & & & & & & & & & & & & \\
\hline & & & $\mathrm{ce}$ & $\mathrm{p}$ & & & & & & & & $\mathrm{Ce}$ & $\mathrm{ce}$ & & & & & & & \\
\hline$<15$ & - & - & - & - & - & 17 & - & 67 & - & 4 & 1 & - & 34 & 8 & 48 & - & 6 & 0 & 16 & 201 \\
\hline 15 & 58 & 220 & 43 & 83 & 404 & 22 & - & 24 & - & 21 & 123 & - & 77 & 125 & 38 & - & 63 & 8 & 6 & 507 \\
\hline 30 & 45 & 62 & 15 & 48 & 170 & 38 & _. & 3 & _ & 32 & 0 & - & 3 & 3 & 7 & - & 6 & 0 & 51 & 143 \\
\hline 50 & 11 & 4 & 7 & 7 & 29 & 6 & - & 1 & - & 14 & 0 & - & 2 & 1 & 5 & - & 2 & 3 & 1 & 35 \\
\hline 100 & 2 & 2 & 1 & 6 & 11 & 0 & _ & 2 & _ & 6 & 1 & _ & 1 & 2 & 0 & - & 1 & 1 & 0 & 14 \\
\hline 200 & 2 & 1 & 1 & 3 & 7 & 1 & - & 0 & _ & 1 & 1 & - & 0 & 0 & 3 & - & 1 & $\hat{0}$ & 0 & 7 \\
\hline 300 & 7 & 8 & 2 & 1 & 18 & 2 & _ & 3 & _ & 4 & 9 & - & 4 & 9 & 6 & _ & 10 & 2 & 1 & 50 \\
\hline 400 & - & 5 & 0 & 1 & 6 & 1 & _ & 2 & _- & 10 & 5 & - & 1 & 2 & 3 & _ & 3 & 2 & 10 & 39 \\
\hline 500 & - & 7 & 1 & 2 & 10 & 2 & _ & 0 & _ & 10 & 1 & - & 1 & 3 & 6 & - & 0 & 1 & 3 & 27 \\
\hline 1000 & - & - & - & - & - & - & 1 & - & 4 & - & - & 0 & - & - & - & 4 & - & - & - & 9 \\
\hline Total & 125 & 309 & 70 & 151 & 655 & 89 & 1 & 102 & 4 & 102 & 141 & 0 & 123 & 153 & 116 & 4 & 92 & 17 & 88 & 1032 \\
\hline \multicolumn{21}{|c|}{$-:$ no trap } \\
\hline
\end{tabular}

A similar distribution pattern was found in 1985. The majority of individuals $(64 \%)$ were caught in the $15 \mathrm{~m}$ traps; above $30 \mathrm{~m}$ rates decreased significantly $(\mathrm{p}<0.01)$. By contrast to 1986, only a slight increase in water layers above $200 \mathrm{~m}$ was observed, which was not statistically significant.

A total of 11 amphipods were recovered from the 4 deployments of the single $1000 \mathrm{~m}$ traps, with 9 specimens in 3 deployments being Eurythenes gryllus. The catch of deployment RK 15, the only one of the single trap units deployed on the Grosser Dreizack, consisted of 2 Cyphocaris richardi.

The vertical distribution of Eurythenes gryllus differed in the 5 age/sex categories. In both years studied, indeterminate juveniles were only trapped up to a distance of $50 \mathrm{~m}$ above the bottom. The majority of specimens were found in the $15 \mathrm{~m}$ traps (Fig. 4a) with mean catch rates of 27 (1985) and 15 (1986) ind. trap ${ }^{-1}$ $\mathrm{d}^{-1}$. Above $15 \mathrm{~m}$, catch rates decreased significantly to between 0.9 and 4.6 ind. $\operatorname{trap}^{-1} \mathrm{~d}^{-1}(\mathrm{p}<0.01)$. 


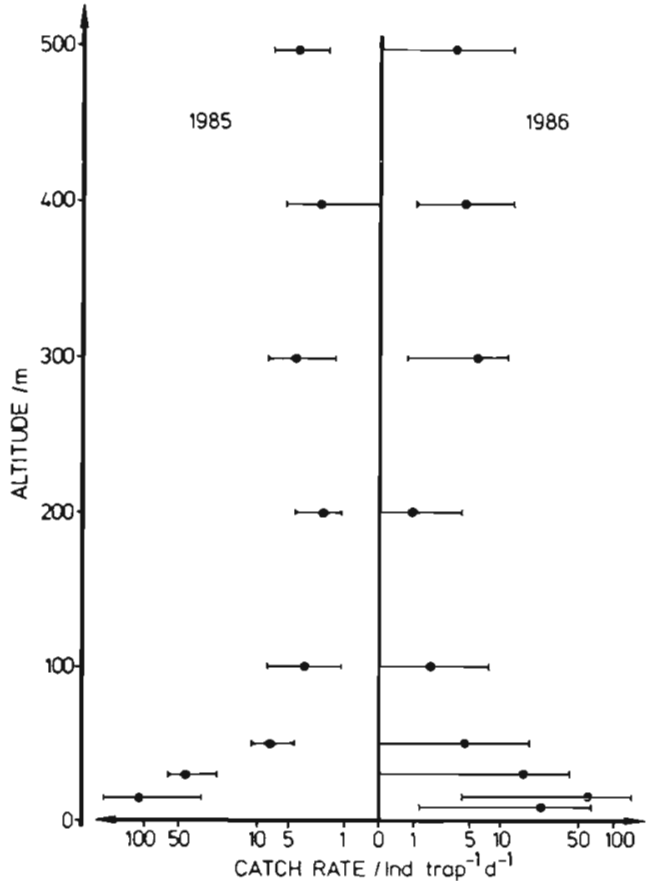

Fig. 3. Eurythenes gryllus. Vertical distribution of all categories. Mean catch rates and ranges at each height above bottom sampled

Immature males were found at all heights above the bottom except $1000 \mathrm{~m}$, with maximum average catch rates of 46 and 21 ind. $\operatorname{trap}^{-1} \mathrm{~d}^{-1}$ at $15 \mathrm{~m}$ (Fig. $4 \mathrm{~b}$ ). Above and below $15 \mathrm{~m}$, their abundance declined significantly ( $p<0.01$ ). From 50 to $500 \mathrm{~m}$, average catch rates were only 0.2 to 2.1 ind $\operatorname{trap}^{-1} \mathrm{~d}^{-1}$.

The distribution of immature females was similar to that of immature males. Again, the majority were caught in the $15 \mathrm{~m}$ traps (Fig. 4c). Average catch rates decreased about an order of magnitude at heights between 15 and $50 \mathrm{~m}$ above the bottom from between 19 and 20 ind $\operatorname{trap}^{-1} \mathrm{~d}^{-1}$ to between 0.3 and 3.8 ind. $\operatorname{trap}^{-1} \mathrm{~d}^{-1}$.

In both years, mature males showed a bimodal vertical distribution pattern with maxima at 15 and $300 \mathrm{~m}$ above the sea floor (Fig. 4d). For the 1986 data, differences between the ranges $<15 \mathrm{~m}$ (mean catch rate 1.4 ind. trap ${ }^{-1} \mathrm{~d}^{-1}$ ), 15 to $30 \mathrm{~m}$ (4.8 ind. $\operatorname{trap}^{-1} \mathrm{~d}^{-1}$ ), 50 to $200 \mathrm{~m}\left(0.53\right.$ ind. $\left.\operatorname{trap}^{-1} \mathrm{~d}^{-1}\right)$ and 300 to $500 \mathrm{~m}$ (2.8 ind. $\operatorname{trap}^{-1} \mathrm{~d}^{-1}$ ) were significant $(p<0.01)$. The increase of average catch rates above $200 \mathrm{~m}$ in 1985 was not significant.

A total of only 16 mature females were trapped in 17 deployments, 10 of them in the $15 \mathrm{~m}$ traps. No mature females occurred in traps higher than $50 \mathrm{~m}$ above the bottom. Females carrying brood were not captured.

The catches in the $1000 \mathrm{~m}$ traps consisted only of large immature females and mature males.

\section{Population structure}

The contingency tables (Tables 3 and 4) show that the proportions of the 5 categories selected were not homogeneous within the 1985 and 1986 deployments. The null hypothesis - proportions are equal in all deployments - has to be rejected by the $\chi^{2}$ test $\left(\chi^{2}=37.1>\chi_{(12,0.01)}^{2}=26.2\right.$ for 1985 and $\chi^{2}=88.6>$ $\chi_{(32,0.01)}^{2}=53.5$ for 1986). A closer examination of the data reveals that the proportions of immature males, mature males and mature females are very similar in all trap sets, whereas there is a large variability in indeterminate juveniles and immature females. The highly significant negative correlation in deviations from expected values for these 2 groups ( $r=-0.957$ ) indicates that the variability is caused by difficulty in discriminating small females from juveniles and not by real differences between stations. Therefore we assumed that the population of Eurythenes gryllus is homogeneous in the area sampled and combined the data from stations of 1985 and 1986, respectively, for analysis of the population structure.

Males were prevalent in all but 2 deployments. The sex ratio $(s=M-F / M+F)$ varied from -0.05 to +0.44 with an overall ratio of +0.17 in 1985 and +0.16 in 1986. The larger indeterminate juveniles are probably also females, because males of more than $2.5 \mathrm{~cm}$ body length are clearly recognizable by the presence of genital papillae, while it is difficult to recognize the oostegites in small females. Thus, the true total sex ratio of the population is probably not appreciably different from 1:1 (i.e., $s=0$ ). There is a trend for increasing male/female ratios with height above bottom (Fig. 5). In both years, the lowest male/female ratio was at $50 \mathrm{~m}$, while the highest ratio occured $300 \mathrm{~m}$ above the bottom. About $25 \%(1985)$ and $36 \%$ (1986) of all males were mature, but only $3 \%$ of females had oostegites with long interlocking setae indicating full maturity, stressing the prevalence of males in the adults, with ratios of +0.86 and +0.89 for 1985 and 1986 respectively.

The size-frequency distribution of Eurythenes gryllus for the combined stations at the heights sampled is shown in Fig. 6 for 1985 and in Fig. 7 for 1986. Large specimens were found at all heights above the sea floor, whereas small specimens with body lengths of less than $4 \mathrm{~cm}$ were nearly absent at heights of more than $50 \mathrm{~m}$ above the bottom. Mean lengths and length ranges are given in Table 5 . The largest individual trapped was a mature female with a body length of $12.9 \mathrm{~cm}$.

The data for both years show a general increase in body length of amphipods with distance from the sea floor (Fig. 8). The small mean sizes in the near-bottom traps were mainly caused by the high proportion of 

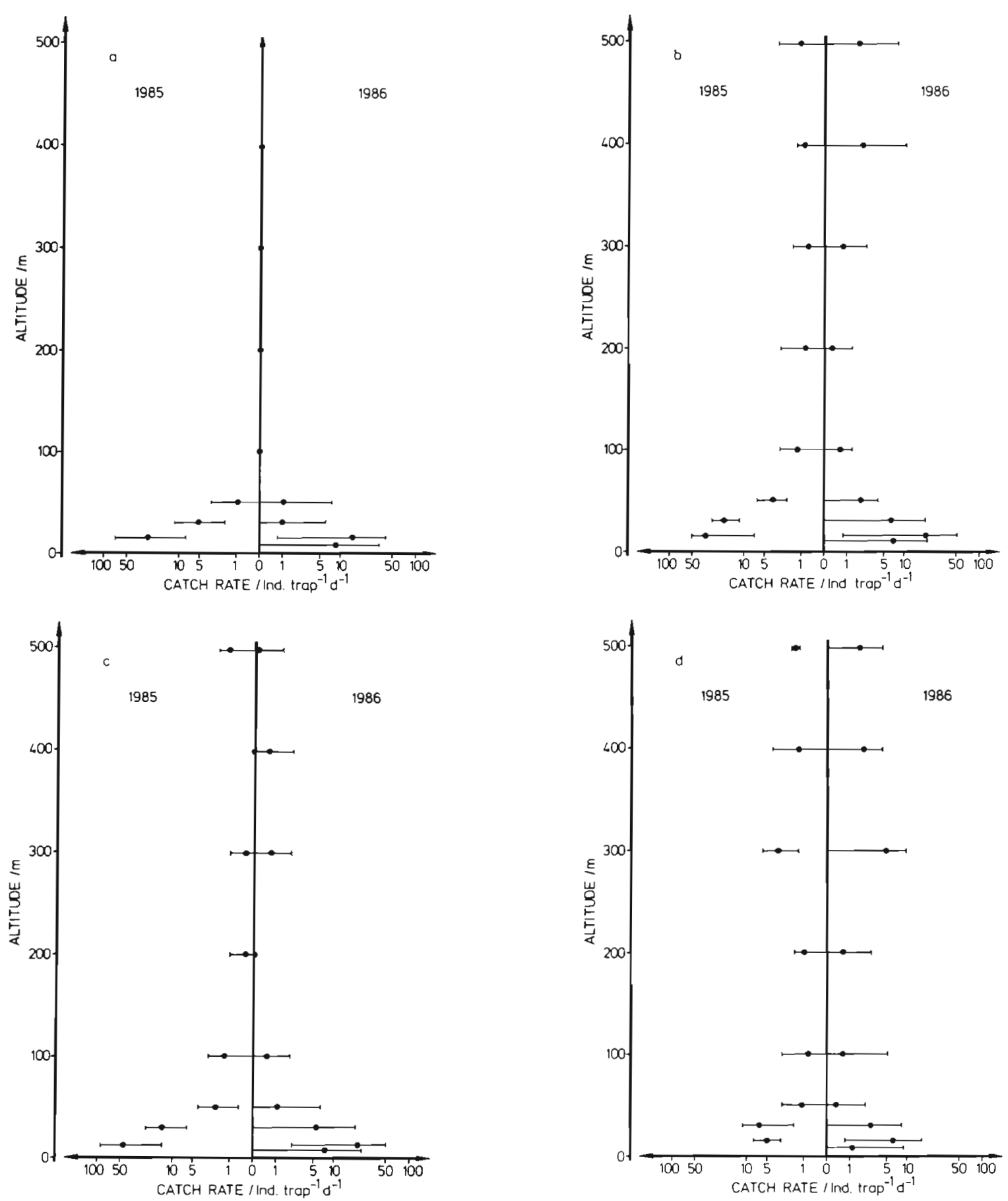

Fig. 4. Eurythenes gryllus. Vertical distributions of (a) indeterminate juveniles, (b) immature males, (c) immature females, (d) adult males

indeterminate juveniles. Above $50 \mathrm{~m}$, where no indeterminate juveniles were trapped, mean body length increased only slightly.

Fig. 9 shows the length-frequency distributions of males and females (all age classes combined) in 1985 and 1986. Several modes can be discriminated, indicating probably non-continuous recruitment. Assuming that indeterminate juveniles larger than $2.5 \mathrm{~cm}$ are females (stippled area in the histograms), the distributions of both sexes in 1985 are quite similar: an increase in numbers was found up to length class $3.75 \mathrm{~cm}$, a second mode occurred in length classes $5.25 \mathrm{~cm}$ (males) and $5.75 \mathrm{~cm}$ (females), followed by a sharp decrease. In 1986, the highest numbers of females 
Table 3. Contingency table for 1985

\begin{tabular}{|c|c|c|c|c|c|c|}
\hline \multirow[t]{2}{*}{ Group } & \multicolumn{4}{|c|}{ Deployment no. } & \multirow[t]{2}{*}{ Sum } & \multirow{2}{*}{$x^{2}$} \\
\hline & 5 & 6 & 7 & 8 & & \\
\hline Indet. juv. & 18 & 78 & 10 & 16 & 122 & 14.4 \\
\hline Imm. males & 37 & 115 & 19 & 63 & 234 & 4.5 \\
\hline Imm. females & 45 & 82 & 33 & 55 & 215 & 9.1 \\
\hline Mat. males & 24 & 30 & 7 & 17 & 78 & 7.1 \\
\hline Mat. females & 1 & 4 & 1 & 0 & 6 & 2.1 \\
\hline Sum & 125 & 309 & 70 & 151 & 655 & \\
\hline$x^{2}$ & 8.5 & 12.9 & 6.9 & 8.8 & & 37.1 \\
\hline
\end{tabular}

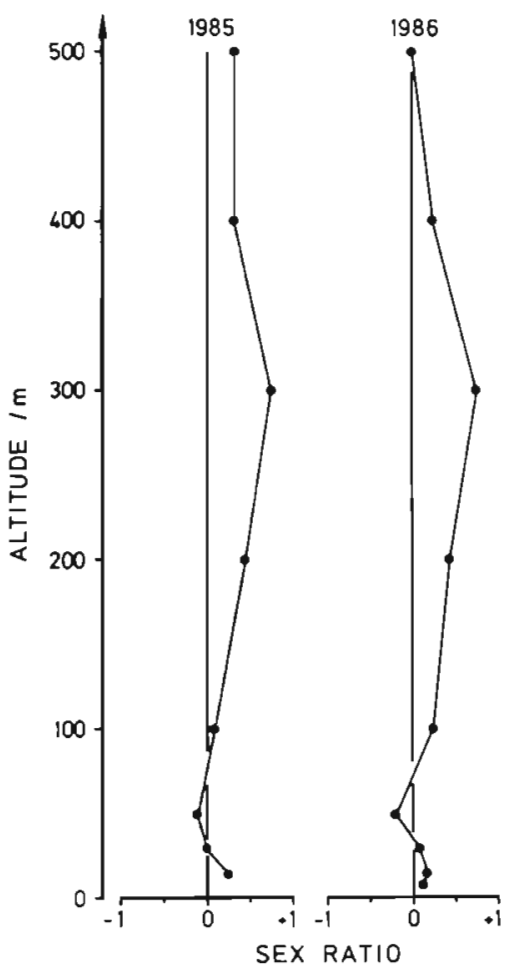

Fig. 5. Eurythenes gryllus. Sex ratio at each height sampled again were in the small size classes with modes at 2.75, 3.75 and $4.75 \mathrm{~cm}$. A further mode can be observed at length class $6.75 \mathrm{~cm}$. Males showed a tendency of increasing numbers up to length class $6.25 \mathrm{~cm}$. Numbers then decreased rapidly. Females obviously grow larger than males: specimens larger than $9.5 \mathrm{~cm}$ were always females.

\section{DISCUSSION}

The vertical distribution of Eurythenes gryllus in the BIOTRANS area appears to follow a clear pattern, with highest numbers in the near-bottom layer and decreasing abundance above $30 \mathrm{~m}$ off the sea floor. Above $200 \mathrm{~m}$, a slight increase in relative abundance could be observed.

This pattern applies for the plains as well as for the peaks of the seamounts, rising up to $700 \mathrm{~m}$ above the plains. Thus the occurrence of Eurythenes gryllus seems to be determined by distance from the sea floor, regardless of absolute water depth. Seamounts therefore have a kind of 'lift effect' for these benthopelagic animals. The similarity of the vertical distribution pattern and homogeneity of the population structure in peak and basin subareas implies a common population of E. gryllus in the area. However, the comparison is limited by the low number of samples per subarea and the high variation in catch rates. Contrary to our findings, Bucklin et al. (1987) reported a genetic isolation of an E. gryllus population living on the crest of a seamount in the North Pacific from populations living in the basins. They suggested that dispersion took place horizontally, separating midwater and crest populations from basin populations. However, the vertical distance between basin and crest was much larger than in the BIOTRANS area.

Analyses of the vertical distribution of scavenger populations derived by means of baited traps have to be interpreted with some caution. The results depend to a large extent on the assumption that the traps

Table 4. Contingency table for 1986

\begin{tabular}{|c|c|c|c|c|c|c|c|c|c|c|c|}
\hline \multirow[t]{2}{*}{ Group } & \multicolumn{9}{|c|}{ Deployment no. } & \multirow[t]{2}{*}{ Sum } & \multirow[t]{2}{*}{$x^{2}$} \\
\hline & 9 & 11 & 13 & 14 & 16 & 17 & 18 & 20 & 22 & & \\
\hline Indet. juv. & 25 & 37 & 19 & 44 & 15 & 27 & 29 & 6 & 9 & 211 & 41.1 \\
\hline Imm. males & 21 & 31 & 32 & 52 & 30 & 49 & 33 & 23 & 25 & 296 & 6.0 \\
\hline Imm. females & 25 & 22 & 36 & 27 & 54 & 51 & 29 & 43 & 37 & 324 & 27.7 \\
\hline Mat. males & 17 & 10 & 14 & 18 & 22 & 26 & 23 & 18 & 17 & 165 & 6.7 \\
\hline Mat. females & 1 & 2 & 1 & 0 & 2 & 0 & 2 & 2 & 0 & 10 & 7.2 \\
\hline Sum & 89 & 102 & 102 & 141 & 123 & 153 & 116 & 92 & 88 & 1006 & \\
\hline$x^{2}$ & 4.1 & 18.7 & 1.2 & 19.7 & 11.5 & 2.8 & 4.3 & 17.7 & 8.9 & & 88.6 \\
\hline
\end{tabular}




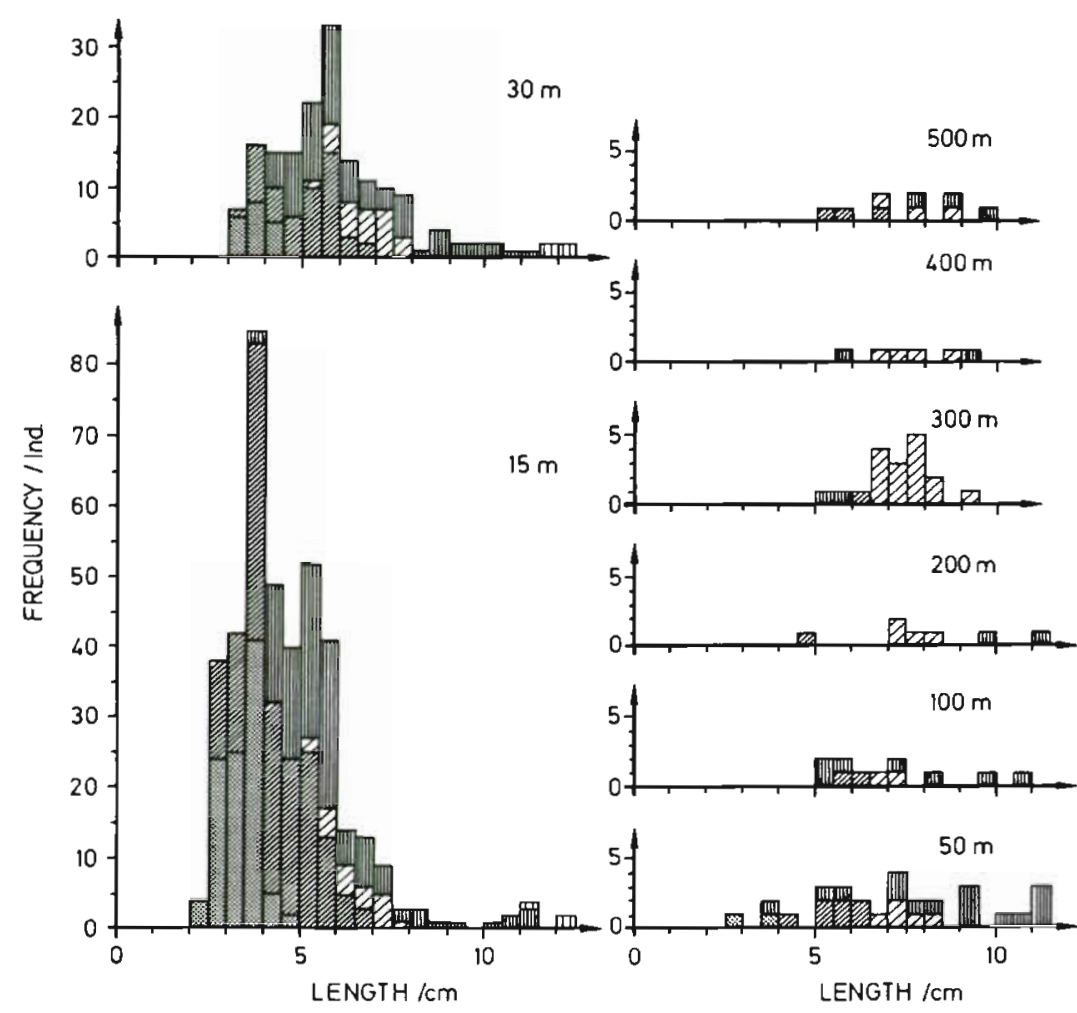

Fig. 6. Eurythenes gryllus. Length-frequency distributions at each height sampled, 1985
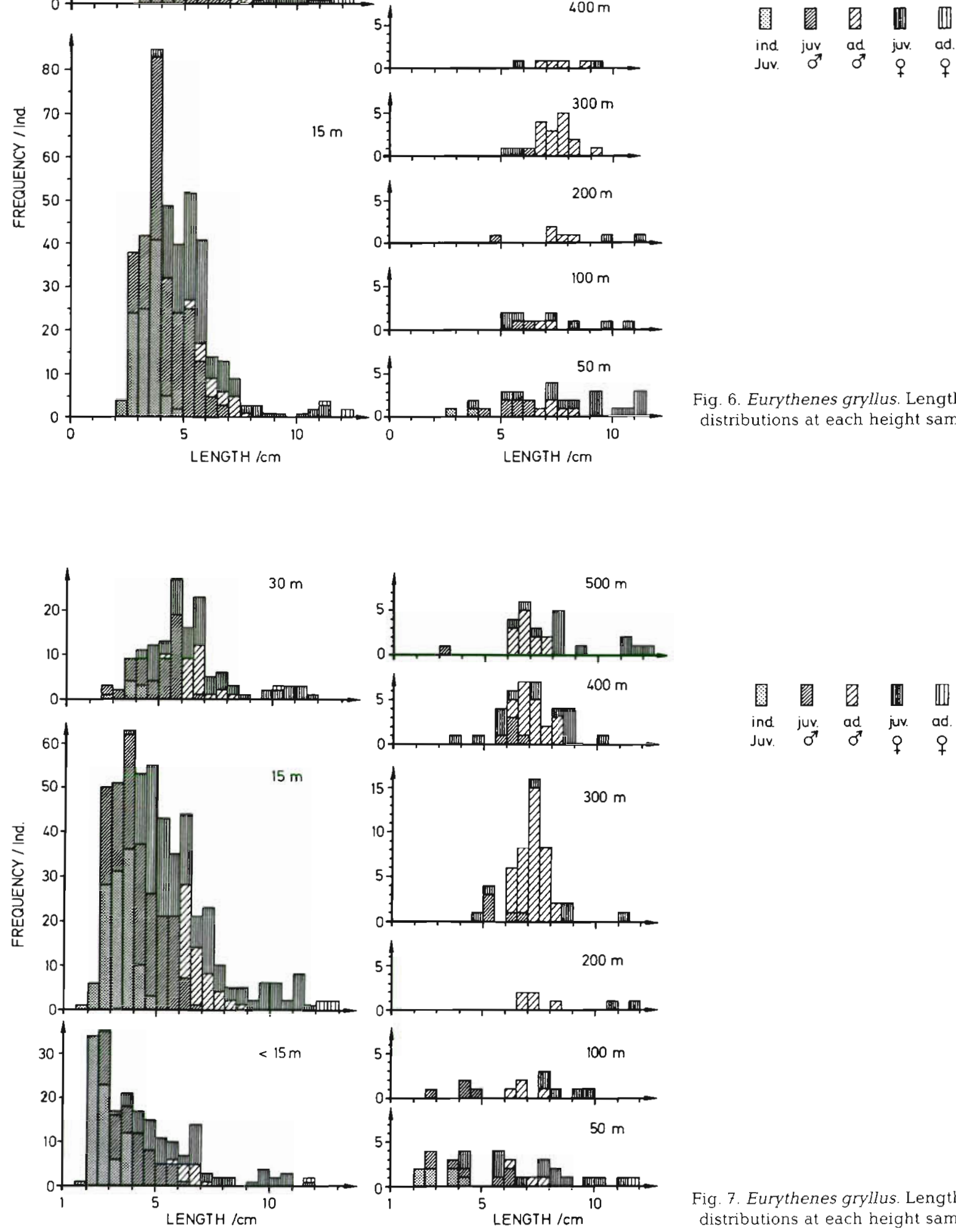

distributions at each height sampled 1985
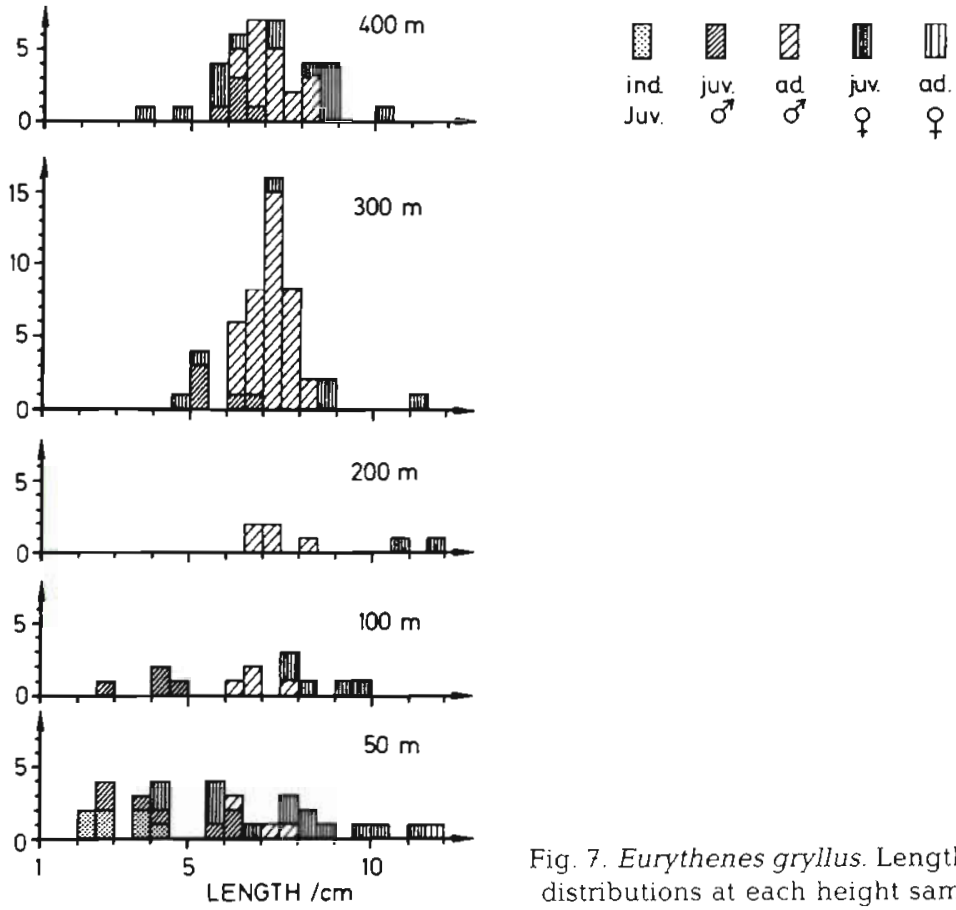

Fig. 7. Eurythenes gryllus. Length-frequency distributions at each height sampled, 1986 
Table 5. Eurythenes gryllus. Mean lengths (geometric means) and length ranges

\begin{tabular}{|lccc|}
\hline Group & $\begin{array}{c}\text { Mean 1985 } \\
(\mathrm{cm})\end{array}$ & $\begin{array}{c}\text { Mean 1986 } \\
(\mathrm{cm})\end{array}$ & \multicolumn{1}{c|}{$\begin{array}{c}\text { Range } \\
(\mathrm{cm})\end{array}$} \\
\hline Juv. & 3.38 & 3.03 & $1.5-5.0$ \\
Imm. males & 4.46 & 4.29 & $2.5-7.0$ \\
Mat. males & 6.96 & 6.88 & $5.0-9.0$ \\
Imm. females & 6.13 & 6.53 & $3.0-12.5$ \\
Mat. females & 12.00 & 11.75 & $10.0-13.0$ \\
\hline
\end{tabular}

exposed at different heights represent the same area of attraction, i.e. the odour plumes generated by the bait are of equal size. Horizontal distribution of odour is mainly caused by advection, thus different current velocities in the depth layers sampled will generate varying sizes of the odour plumes.

The intermediate minimum of amphipods trapped in the layer 100 to $200 \mathrm{~m}$ may for instance be related to a minimum in current velocities, as observed by Mittelstaedt (1986) and Klein (1987).

Because scent is dispersed not only horizontally but also vertically (Sainte-Marie \& Hargrave 1987), it is certain that animals are also attracted from layers below or above a trap. This may explain the varying proportions of amphipods caught between the traps 5 to $30 \mathrm{~m}$ above the bottom, where the vertical distance between traps was relatively short and thus the possibility of interference greater than between upper traps.

Additionally, social behaviour, as discussed by

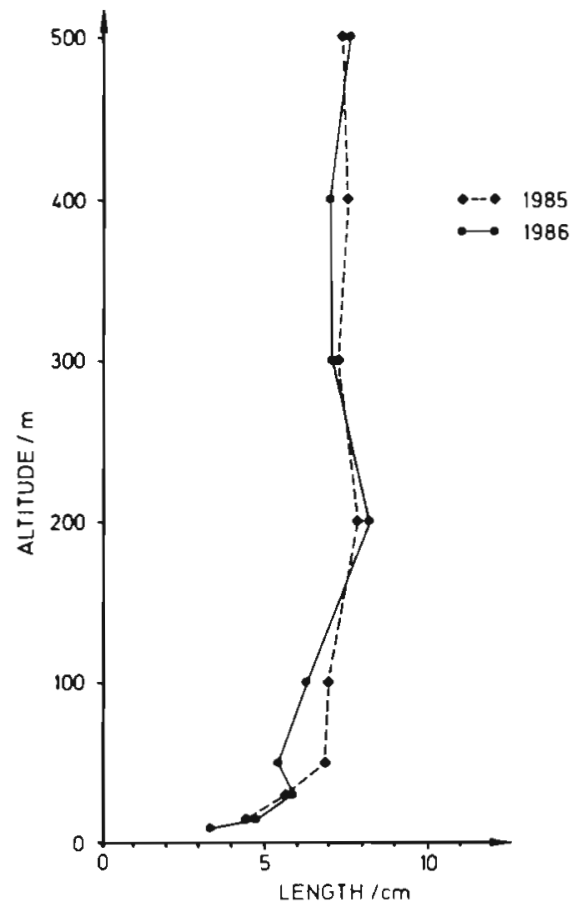

Fig. 8. Eurythenes gryllus. Mean body length versus height above bottom

Ingram \& Hessler (1983), and an additional attraction by means other than olfaction, e.g. noise generated by chewing mouthparts (Smith \& Baldwin 1984), could also bias the results on vertical distribution.

Despite the restrictions of the methodology, the

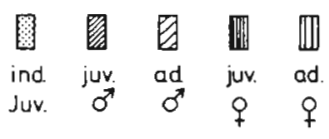

Fig. 9. Eurythenes gryllus. Lengthfrequency distribution in 1985 and 1986 . combined stations and altitudes. Left: males; right: females
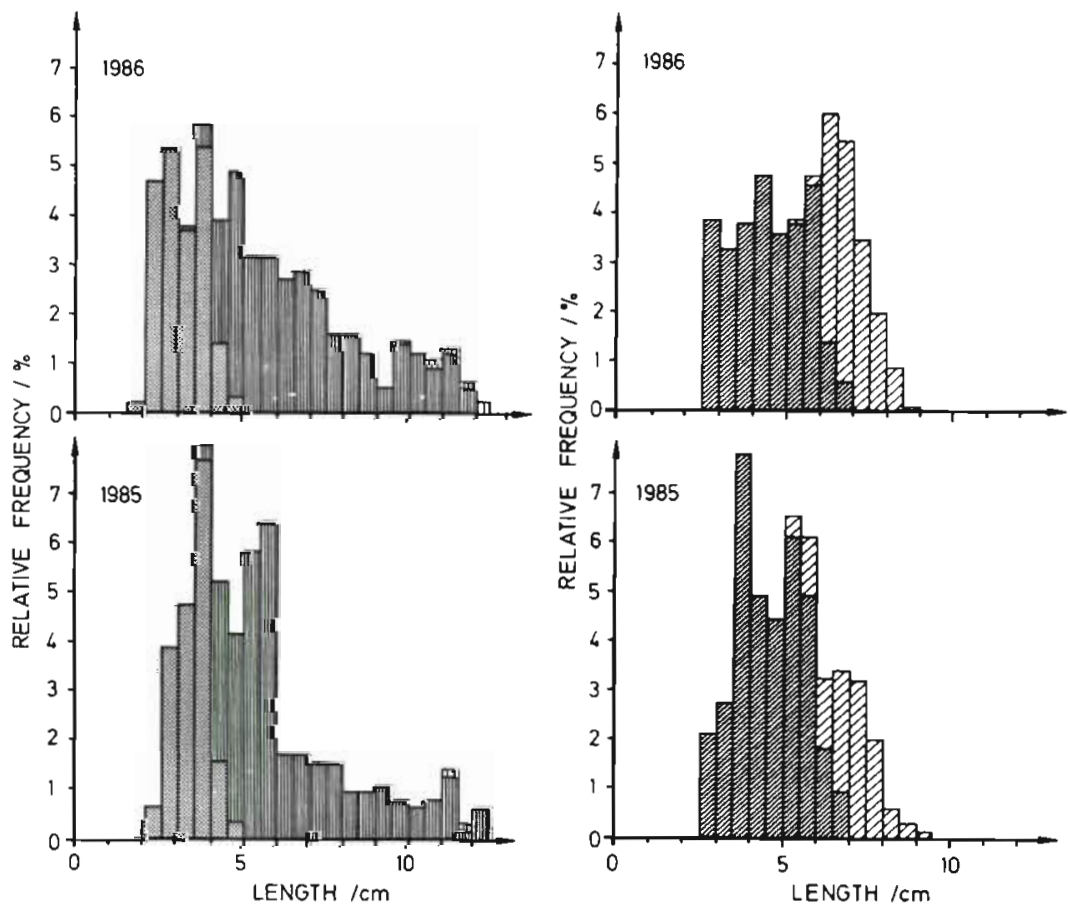
observed vertical distribution pattern of Eurythenes gryllus appears to be a common feature of this species in different parts of the world's oceans, regardless of environmental differences. In the North Pacific, a simiIar pattern, but without an intermediate minimum, was found by Ingram \& Hessler (1983), Smith \& BaIdwin (1984) and Baldwin \& Smith (1987). In the Atlantic southeast of the BIOTRANS area, Charmasson \& Calmet (1987) also reported a rapid decrease of catch rates above 10 to $20 \mathrm{~m}$ from the bottom.

Some information on the population dynamics of Eurythenes gryllus can be derived from the sizefrequency distributions. However, discrete size groups representing instars are not clearly recognizable, although there is some indication for polymodality in the histograms. Probably the class intervals of $0.5 \mathrm{~cm}$ are too large and obscure sharp delineations, as found by Thurston (1979), Baldwin \& Smith (1987) and Ingram \& Hessler (1987), using size intervals of 1 or $0.5 \mathrm{~mm}$. Relatively low numbers in the smallest size groups, which prefer the near-bottom layers, are probably an artifact because the lowest traps were at least $5 \mathrm{~m}$ above the sediment, in 1985 even $15 \mathrm{~m}$.

Generally, the size-frequency diagrams show a trend for decreasing numbers with increasing length. The number of males declines rapidly beyond a length of $7 \mathrm{~cm}$, indicating high mortality in these size groups. However, mortality seems low for females larger than $6 \mathrm{~cm}$ : in both years, numbers of successive length classes show only a slight decrease.

The high prevalence of males in the adults is caused by their earlier maturity. They reach maturity at Instar VIII (Ingram \& Hessler 1983) at a length of 5 to $7 \mathrm{~cm}$. The smallest mature females trapped had a body length of $10 \mathrm{~cm}$. While growing to this length they still suffer mortality.

The occurrence of modes in different size classes may be an indication for non-continuous recruitment. Comparison of the successive years reveals a shift of modes which might indicate the growth of cohorts between the sampling dates. In 1985, the peaks of abundance for males are in length classes 3.75 and $5.25 \mathrm{~cm}$. The corresponding modes in 1986 in length classes 4.25 and $6.25 \mathrm{~cm}$ point to an annual growth of about 0.5 to $1.0 \mathrm{~cm}$. For females, the modes are shifted from 3.75 and $5.75 \mathrm{~cm}$ in 1985 to 4.75 and $6.75 \mathrm{~cm}$ in 1986, also implying an annual growth of about $1 \mathrm{~cm}$. This is less than rates calculated from data of Ingram \& Hessler (1987) for the Pacific. These authors reported a shift in peak abundance from Instar III to Instar $\mathrm{V}$ in successive years. The mean length in Instar III was $3.2 \mathrm{~cm}$, in Instar V $4.8 \mathrm{~cm}$ (males) and $5.0 \mathrm{~cm}$ (females), giving an annual growth of nearly $2 \mathrm{~cm}$

The comparison of modes between males and females shows that in both years peak abundances of males are in lower length classes than that of females. If the modes in both sexes represent the same year classes, this would indicate a higher growth rate for females than for males

Very small juveniles of 1.5 to $2.5 \mathrm{~cm}$ were only found up to $15 \mathrm{~m}$ above the sea floor, with the exception of 2 individuals trapped at $50 \mathrm{~m}$. The proportion of this group decreases from $18 \%$ of all juveniles in traps at $10 \mathrm{~m}$ above bottom to $3 \%$ at $15 \mathrm{~m}$. These observations fit well with the findings of Thurston (1979) in the North Atlantic: only juvenile Eurythenes gryllus were caught in a trap deployed directly on the sediment, nearly $85 \%$ of them from 15 to $25 \mathrm{~mm}$ length.

The fact that small juveniles and mature females were only found within $50 \mathrm{~m}$ above the sediment leads to the conclusion that reproduction takes place near the bottom. The bimodal distribution of adult males with a second peak of abundance at $300 \mathrm{~m}$ above the sediment is somewhat contradictory to this hypothesis. Although there was still a large proportion of adult males near the bottom it is not clear why nearly half of the adult males occurred higher than $200 \mathrm{~m}$. One explanation may be that large females trapped in higher layers without long setae on their oostegites are adult too, but in a preparatory stage before a brood. Multiple brooding with a reduction of marginal setae on the oostegites between broods is common in shallow-water amphipods (Steele \& Steele 1975). Little is known about the mating behaviour of deep-sea lysianassids. Other gammaridean males seize the females before the parturial moult, i.e. before the oostegites are fully developed, and wait for copulation until the moult takes place. This points to the possibility that mating also occurs in higher layers.

Thus the development of Eurythenes gryllus might be a follows: females release their brood near the sediment. The youngest stages stay within a few meters of the bottom, probably feeding on small detrital particles rather than on larger food items. For larger specimens feeding on large particles it might be advantageous to keep a certain distance from the sea floor to have a 'larger chemosensory view of the sediment' (Ingram \& Hessler 1983). The zone of maximum abundance lies within the benthic boundary layer where maximum turbulent diffusion occurs, reaching 20 to $80 \mathrm{~m}$ above bottom in the BIOTRANS area (Mittelstaedt 1986). It is also possible that older stages are capable of predation with some degree of independence from descending food. Some indication for predatory behaviour in E. gryllus was found by Templeman (1967). Mating probably occurs in all water layers. Females with brood then descend to the near-bottom layer. The reason that ovigerous females have never been trapped may be that they do not feed at all, or that they are extremely rare. 
The vertical separation of developmental stages in the water column implies that Eurythenes gryllus migrates vertically, at least on an ontogenetic scale. E. gryllus is thus responsible for a bidirectional vertical transport of organic matter in and above the benthic boundary layer of the deep-sea. For an estimation of the amount of organic matter transported it would be necessary to obtain quantitative data on the abundance and on population parameters, as growth and mortality, of these scavenging amphipods.

Acknowledgements. We thank the officers and crews of the research vessels 'Polarstern', 'Meteor (I)' and 'Meteor (II)' for their helpful cooperation. We are indebted to V. Nuppenau, who designed the trap set and was always ready to help in solving technical problems, and to Dr R. Baldwin and S. Diel for critical comments on the manuscript. The investigations were funded by the Bundesministerium für Forschung und Technologie, Federal Republic of Germany (MFU 0544/9).

\section{LITERATURE CITED}

Baldwin, R. J., Smith, K. L. Jr (1987). Temporal variation in the catch rate, length, color and sex of the necrophagous amphipod, Eurythenes gryllus, from the central and eastern North Pacific. Deep Sea Res. 34: 425-439

Bucklin, A., Wilson, R. R., Jr, Smith, K. L., Jr (1987). Genetic differentiation of seamount and basin populations of the deep-sea amphipod Eurythenes gryllus. Deep Sea Res. 34: $1795-1810$

Charmasson, S. S., Calmet, D. P. (1987). Distribution of scavenging Lysianassidae amphipods Eurythenes gryllus in the northeast Atlantic: comparison with studies held in the Pacific. Deep Sea Res. 34: 1509-1523

Heinrich, H. (1986). Bathymetrie und Geomorphologie des NOAMP-Gebietes, Westeuropäisches Becken $\left(17^{\circ} \mathrm{W}\right.$ bis $22^{\circ} \mathrm{W}, 46^{\circ} \mathrm{N}$ bis $49^{\circ} \mathrm{N}$ ). Dt. hydrogr. Z. 39: $183-196$

Ingram, C. C., Hessler, R. R. (1983). Distribution and behavior

This article was submitted to the editor of scavenging amphipods from the central North Pacific. Deep Sea Res. 30: 683-706

Ingram, C. C., Hessler, R. R. (1987). Population biology of the deep-sea amphipod Eurythenes gryllus: inferences from instar analysis. Deep Sea Res. 34: 1889-1910

Klein, H. (1987). Benthic stormes, vortices, and particle dispersion in the deep West European Basin. Dt. hydrogr. Z. 40: 87-102

Mittelstaedt, E. (1986). Ausbreitungsbedingungen für Stoffe in grossen Ozeantiefen. Report, Deutsches Hydrographisches Institut, Hamburg

Nyffeler, F., Godet, C.-H. (1986). The structural parameters of the benthic nepheloid layer in the northeast Atlantic. Deep Sea Res. 33: 195-207

Sachs, L. (1978). Angewandte Statistik. Springer-Verlag, Berlin

Sainte-Marie, B., Hargrave, B. T (1987). Estimation of scavenger abundance and distance of attraction to bait. Mar. Biol. 94: 431-443

Smith, K. L. Jr, Baldwin, R. J. (1984). Vertical distribution of the necrophagous amphipod, Eurythenes gryllus, in the North Pacific: spatial and temporal variation. Deep Sea Res. 31: 1179-1196

Smith, K. L., White, G. A., Laver, M. B., McConnaughey, R. R., Meador, J. P. (1979). Free vehicle capture of abyssopelagic animals. Deep Sea Res. 26: 57--64

Sokal, R. R., Rohlf, F. J. (1969). Biometry. W. H. Freemand, San Francisco

Steele, D. H., Steele, V J. (1975). The biology of Gammarus (Crustacea, Amphipoda) in the north-western Atlantic. XI. Comparison and discussion. Can. J. Zool. 53: 1116-1126

Templeman, W. (1967). Predation on living fishes on longline in Baffin Bay by the amphipod Eurythenes gryllus (Lichtenstein), and a new distribution record. J. Fish. Res. Bd Can. 24: 215-217

Thiel, H. (1986): Die Expedition Antarktis IV mit F.S. 'Polarstern' 1985/86: Bremerhaven - Vigo/ Las Palmas (ANT IV/1a). Ber. z. Polarforschung 32: 9-42

Thurston, $M$. H. (1979). Scavenging abyssal amphipods from the North-East Atlantic Ocean. Mar. Biol. 51: 55-68

Wickins, J. F. (1983). Catches of large lysianassid amphipods in baited traps at the Nuclear Energy Authority dump site during June 1979. Deep Sea Res. 30: 83-86

Manuscript first received: May 2, 1989

Revised version accepted: April 27, 1990 